Suicidality and suicide prevention in culturally and linguistically diverse (CALD) communities: A systematic review

Madeleine Bowden $^{\mathrm{a} *}$, Alicia McCoy ${ }^{\mathrm{a}}$, Nicola Reavley ${ }^{\mathrm{b}}$

${ }^{a}$ Beyond Blue, Melbourne, Australia

${ }^{b}$ Centre for Mental Health, Melbourne School of Population \& Global Health, The University of Melbourne, Melbourne, Australia

*Corresponding author. Contact: Madeleine Bowden, madeleine.bowden@beyondblue.org.au, Beyond Blue, Melbourne, Australia 


\title{
Suicidality and suicide prevention in culturally and linguistically diverse (CALD) communities: A systematic review
}

\begin{abstract}
Australia has one of the largest multicultural populations in the world, with cultural and linguistic diversity (CALD) a defining feature. CALD populations have unique identities and experiences of mental health and suicide, with multicultural differences, trauma and experiences of discrimination and stigma pertinent to effective suicide prevention approaches. Very little is known however about suicide and suicidality among this population in Australia. This systematic review explored literature on suicidality and suicide prevention in CALD communities as a means of informing suicide prevention research, policy and practice in the Australian context. Five electronic databases (Medline, PsycINFO, Embase, Emcare, and CINAHL) were searched. Studies were included if they examined factors associated with suicidality or described suicide prevention initiatives in CALD populations, and were conducted in OECD countries. Study quality was assessed using the CASP qualitative checklist for qualitative studies and the Quality Assessment Tool for quantitative studies. Thematic analysis was used to identify key themes in the included studies. Eighteen studies met the criteria for inclusion, including ten qualitative and eight quantitative studies. No Australian studies were identified. Key themes included acculturation difficulties, stigma, the influence of social networks and family, heterogeneity of CALD populations, and suggested prevention strategies. The review found no Australian studies looking at suicidality or suicide prevention in CALD communities. It highlights the need for a greater focus across policy, research and evaluation on suicide prevention in Australian CALD communities.
\end{abstract}

Keywords: suicide, prevention, mental health, cultural and linguistic diversity, immigrant, refugee

Disclosure statement: The authors have no conflicts of interest to declare. 


\section{Introduction}

Suicide presents a significant public health concern, affecting all regions of the world, including both high- and low-income countries. Globally, the World Health Organization estimates that close to 800,000 people die by suicide every year (World Health Organization, 2018a). Rates of suicide attempts are estimated at around 20 times this number, and suicide bereavement is said to affect between 48 million and 500 million people each year (World Health Organization, 2018a). Prevention therefore, is a central concern for policy makers and health care professionals all over the world.

Suicide is a complex phenomenon resulting from multiple biological, psychological, social and cultural factors (Zaheer, Eynan, Lam, Grundland, \& Links, 2018). As a result, risk factors vary across different populations and sociodemographic groups, with several high-risk groups identified in the literature. In some studies, immigrants, refugees and ethnic minorities have been found to be at increased risk of suicidal behaviour compared to their host populations, whereas others have found rates to be lower than the host population (Forte et al., 2018). Research has found a relationship between immigration and higher rates of psychological distress and mental illness which is thought to be a key risk factor for suicide (Fazel, Wheeler, \& Danesh, 2005). Other common risk factors for suicide in this population include difficulties with cultural assimilation and acculturation, social isolation, language barriers, and separation from family (Lai, Li, \& Daoust, 2017).

Australia has one of the largest multicultural populations in the world, with cultural and linguistic diversity a defining feature (Minas et al., 2013). In 2018, there were approximately 7.3 million migrants living in Australia (out of a total population of 25 million) (Australian Bureau of 
Statistics, 2018). As a result, people from culturally and linguistically diverse backgrounds are a priority population for suicide prevention in Australia. The term Cultural and Linguistic Diversity (CALD) was introduced by the Australian Bureau of Statistics (ABS) in 1999 as a broad descriptive measure to identify the various multicultural populations living in Australia (Australian Bureau of Statistics, 1999). CALD replaces the previous designation "non-English language speaking' and was intended to capture a wider subset of the population under the one descriptor. In most population and census data in Australia, country of birth is the primary indicator of CALD status.

CALD populations have unique identities and experiences of mental health and suicide, with multicultural differences, trauma and experiences of discrimination and stigma pertinent to effective suicide prevention approaches (Life in Mind, 2019). Very little is known about suicide and suicidality among this population in Australia, with current data sources said to be not sufficiently complete, comprehensive or accessible to answer key suicide prevention questions (Sutherland et al. 2017). Currently in Australia, only Queensland and Victoria collect surveillance data on suicide, with the Queensland Suicide Register (QSR) and Victorian Suicide Register (VSR) collecting data dating back to 1990 and 2009 respectively. In their most recent report, for the period 2011-2013, the QSR recorded 389 (20.3\%) suicide deaths for people born outside Australia. This was a rate of 8.41 deaths per 100,000 people, which was lower than the overall rate for Queensland and Australia (13.42 and 15.12 deaths per 100,000 people respectively) (Potts, 2015). Similarly, for the period 2009-2019 in Victoria, 239 people of CALD backgrounds died by suicide (representing $21.2 \%$ of the total number of deaths by suicide) (Sutherland et al., 2018). A study by Ide and colleagues (2012) found that rates of suicide among first generation migrants between 1974 and 2006 varied considerably depending on country of birth, and that suicidal 
behaviour is "influenced by the cultures, traditions, ethnicities and, possibly, genetic predispositions of their homelands" (p.1922). A follow up study in 2014 examined suicide rates of second-generation immigrants in Australia and found no difference between first and secondgeneration migrants (Law, Kolves, \& De Leo, 2014). Beyond this, no further research was found examining factors associated with suicidality among CALD populations in Australia. Research on mental illness - a key risk factor for suicide (World Health Organization, 2018b) - is also scarce in this population, with a 2012 report from Mental Health in Multicultural Australia concluding that research findings on the prevalence of mental health disorders in immigrant and refugee populations were "incomplete and contradictory" (Minas, Klimidis \& Kokanovic, 2013, p.29).

Prevention efforts for suicide among CALD communities in Australia are also limited. An assessment of activities funded as part of the Australian Federal Government's National Suicide Prevention Programme showed that the uptake of mainstream suicide prevention initiatives by CALD communities was poor, and that there were only a handful of small scale suicide prevention programs targeted specifically at people from CALD backgrounds (Australian Government Department of Health, 2014; 2018). Furthermore, there have been no studies or evaluations examining the effectiveness of these programs, nor any research into suicide prevention more broadly within this population in Australia. To inform suicide prevention efforts for any population, it is important to understand the factors associated with suicidality, as well as considering the effectiveness of suicide prevention efforts elsewhere. Therefore, the aim of this paper was to review the international literature on suicidality and suicide prevention in CALD communities as a means of informing suicide prevention research, policy and practice in the Australian context. 


\section{Methods}

This systematic review was conducted in accordance with the PRISMA recommendations for systematic reviews (Liberati et al., 2009).

\section{Eligibility criteria}

Studies were included if they met the following criteria:

- Examined factors associated with suicidality (i.e., suicidal ideation, suicide attempts or suicide plans), suicide deaths or suicide prevention in CALD populations. Studies examining prevalence rates were not included).

- Described suicide prevention interventions in CALD populations.

- Were conducted in western countries, to ensure comparability with Australia. Western countries in this context were defined as members of the Organization for Economic Cooperation and Development (OECD) and include Australia, Austria, Belgium, Canada, Czech Republic, Denmark, Finland, France, Germany, Greece, Iceland, Hungary, Republic of Ireland, Italy, Japan, Luxembourg, Mexico, Netherlands, New Zealand, Norway, Poland, Portugal, Slovakia, South Korea, Spain, Sweden, Switzerland, Turkey, United Kingdom, and the United States.

- Used qualitative or quantitative methods.

- Were published in English (given the Australian context).

- Were published in 2000 or later (to ensure the most up to date research was captured).

As a term introduced by the Australian Bureau of Statistics (ABS), CALD is a term not commonly used outside of the Australian literature. The ABS outlines the following variables 
which constitute CALD status: country of birth; country of birth of father; country of birth of mother; ancestry; religious affiliation; year of arrival in Australia; proficiency in spoken English; first language spoken; main language spoken at home; main language other than English spoken at home; languages spoken at home (with a minimum of four variables required to meet the definition) (ABS, 1999). As a result, inclusion criteria were broadened to include refugees, immigrants (including both first and second generation populations), ethnic minorities and multicultural populations. MeSH (Medical Subject Headings) terms were used to identify other related search terms. Aboriginal and Torres Strait Islander and Indigenous groups were excluded because they have unique experiences of suicide specific to the Australian context, which is outside the scope of this review.

\section{Identification and selection of studies}

Literature was identified through a search of five online databases on 19 March 2019, including Medline, PsycINFO, Embase, Emcare, and CINAHL. These databases were selected because of their focus on mental health, population health, psychology and human behaviour. Reference lists of several key papers were also searched for additional citations. A full list of search terms is shown in Figure 1.

[Figure 1 goes here]

\section{Data extraction and analysis}

Data were extracted from qualitative and quantitative studies separately due to the substantial differences in methodology and presentation of findings. For qualitative studies, country, data collection, sampling methodology, study population, sample size, area of focus and key findings 
were extracted. For quantitative studies country, data collected, sampling methodology, sample size, study population, area of focus and key findings were extracted.

Thematic analysis was undertaken for all included studies and guided by three steps. Step one involved reading and reviewing in detail the included full text articles. In step two, key factors related to suicidality in the population of interest, prevention, intervention and future recommendations were summarised and reviewed. In step three, common factors and themes were grouped together under several broader themes.

In addition to examining study methodology and data collection strategies, sample size, general area of focus and the findings were also extracted. Further, findings were examined with specific attention to the factors associated with and influencing suicidality, prevention and intervention strategies, and recommendations for future prevention activities.

\section{Quality assessment}

Methodological quality of the qualitative studies was assessed using the Critical Appraisal Skills Programme (CASP) qualitative checklist (CASP, 2018). This tool contains a list of nine checklist criteria for assessing the following areas: aims, methodology, design, data collection, data analysis, ethical considerations, interpretation, findings and value of the research. Studies which meet 8-9 of the criteria are considered to be high quality; 6-7 of the criteria are moderate quality; and those which meet less than six criteria are considered to be poor quality. Quantitative studies were assessed using the Quality Assessment Tool for Quantitative Studies (Effective Public Health Practice Project, 1998). This tool comprises eight components (selection bias, study design, confounders, blinding, data collection methods, withdrawals and dropouts, intervention integrity and analysis) which are scored as strong, moderate or weak. The total rating of a study is 'strong' 
if none of its components are rated 'weak'. Studies are rated as 'moderate' if only one of its components was rated 'weak'; and rated as 'weak' if two or more of its components are rated as 'weak'. Although the instrument assesses the integrity of the intervention and analyses (e.g., analysis by intention to treat status), this was not applicable for the studies included in this review, and therefore excluded for the purposes of this review.

\section{Results}

The search generated a total of 715 citations. Abstracts were screened to identify studies that met the eligibility criteria. After application of these criteria at the title and abstract stage, 31 articles were included for full text review. A further five citations were identified through a manual search of the reference lists of selected papers. Full text articles were read to confirm they met the inclusion and exclusion criteria with 18 studies excluded at this point to produce 18 papers for inclusion in the final analysis. (See Figure 2). Citations were managed using EndNote X9 reference management software (EndNote, 2019).

[Figure 2 goes here]

\section{Study characteristics}

Study characteristics are outlined in Tables 1 (qualitative studies) and 2 (quantitative studies). Of the 18 included studies, five were from the US, three from Canada, two from Germany, two from The Netherlands, and one each from Sweden, France, Switzerland, Norway and Greece. One study utilised multicentre data from 11 European countries.

[Tables 1 and 2 go here] 


\section{Qualitative studies}

Ten of the 18 studies utilised qualitative research methods. Sample sizes ranged from 10 to 83 . Two studies used focus groups; five used semi-structured individual interviews; two used psychological autopsies and one used both semi-structured interviews and focus groups. Two studies were conducted with females only, and all 10 studies included only adult participants. Three studies were concerned with Bhutanese refugees living in the US. The remaining seven were concerned with immigrants living in other countries, including: Chinese immigrants in the US, Asian immigrants living in the US, Chinese immigrants living in Canada, Korean immigrants living in Canada (two studies), Turkish immigrants living in Germany, and immigrants generally living in Greece. Two studies examined data from people who had died, with a focus on risk factors associated with death by suicide (one comparing immigrants to national population). The remaining eight studies collected data from those who had either attempted suicide (two studies), those who had identified as having suicidal behaviours or suicidality (five studies), or from community members affected by suicide bereavement (one study).

\section{Quality assessment}

Using the CASP tool, four of the ten studies were rated as poor quality, three were rated as moderate quality, and three rated as high quality. The main methodological limitations related to the lack of justification for sample size, selection bias and observer bias. (See Table 3).

[Table 3 goes here]

\section{Quantitative studies}

Eight of the 18 studies utilised quantitative research methods. Sample sizes ranged from 185 to 4.4 million. All eight studies collected demographic data, with three studies using validated 
psychometric instruments. Five studies used existing datasets and conducted retrospective data analysis (including two national registry datasets). One study examined women only, and two studies examined adolescents only. Two studies examined the experience of specific immigrant groups living in other countries, including Turkish women living in Germany and Turkish women

in The Netherlands. Four studies examined the experience of those with an immigrant background living in other countries, including one from Norway, one from France, one from The Netherlands and one from the WHO/EURO multicentre study (which included data from 11 countries). The remaining two studies were based on national registry data and utilised immigrant status and country of birth as defining variables. Two studies examined suicide deaths, three studies examined suicide attempts, and three studies examined suicide ideation or suicidal behaviour.

\section{Quality assessment}

Using the Quality Assessment Tool for Quantitative Studies, the overall quality of the quantitative studies was mixed, with six rated as weak, and two rated as moderate. The main methodological limitations related to the overall study design (i.e., not randomised and reliance on cross-sectional, once-off data collection methods), lack of blinding of participants, and selection bias. (See Table 4).

[Table 4 goes here]

\section{Key themes}

Several key themes were observed across the 18 included studies. These included acculturation difficulties, stigma, the influence of social networks and family, heterogeneity of CALD populations, and suggested prevention strategies. 


\section{Theme 1: Acculturation difficulties}

Acculturation refers to the process of integration or assimilation into another culture. More broadly it refers to "changes in beliefs, attitudes, values and behaviours - generally as a result of migration from one country to another" (Zaheer et al., 2018, p.505). Acculturation stress describes the psychological difficulties which arise during the acculturation process as a result of the conflict between trying to maintain one's own culture while trying to adapt to a new culture (Berry, 1997). Seven studies pointed to acculturation difficulties as a risk factor for suicidality (Brown et al., 2019; Buszstien et al., 2012; Chung, 2012; Eylem et al., 2019; van Leeuwen, Rodgers, Regner \& Charbrol, 2010; Zaheer et al., 2018). Resettlement challenges, including language barriers, culture shock, employment difficulties, and financial stress were most commonly reported. These findings were observed across studies from a range of host countries including USA, France, Canada and

The Netherlands, as well as in the WHO/EURO multicentre study, and in both the qualitative and quantitative literature. Several studies found that greater adherence to one's ethnic culture was associated with a higher risk of suicide in immigrants and refugees, whereas active participation in the host culture acted as a protective factor against suicide (Eylem et al., 2019; van Leeuwen, Rodgers, Regner \& Charbrol, 2010). Consideration and awareness of acculturation issues was highlighted by several studies as being necessary for effective suicide prevention initiatives (Brown et al., 2019; Eylem et al., 2019; Zaheer et al., 2018).

\section{Theme 2: Stigma}

Stigma, which is defined as a mark of disgrace or infamy, or a reproach on one's reputation (Barney, Griffiths, Jorm \& Christensen, 2006), was highlighted by five studies as a key barrier to help-seeking for suicidal ideation and behaviour (Chung, 2012; Han \& Oliffe, 2015; Heredia 
Montesinos et al., 2019; Paraschakis et al., 2014; Puzo, Mehlum \& Qin, 2018). Stigma most commonly stemmed from cultural norms and shame associated with suicide and mental illness. Self-stigma about having a mental illness was also highlighted. This stigma often also related to family and social pressure, and the need to maintain a good reputation within the community. This theme was highlighted in Turkish women (Heredia Montesinos et al., 2019), Asian immigrants (Chung, 2012) and Korean-Canadian immigrants (Han \& Oliffe, 2015). Anti-stigma awareness campaigns were cited in two studies as a possible way to help improve help-seeking behaviour (Heredia Montesinos et al., 2019; Puzo, Mehlum \& Qin, 2018).

\section{Theme 3: Social networks and family}

Family relationships and social support were found to influence suicidal behaviour - as both risk and protective factors. Nine studies pointed to family relationships and/or social support as a contributing factor to suicidality (Brown et al., 2019; Chase \& Sapkota, 2017; Chung, 2012; Chung, Caine, Barron \& Badaracco, 2015; Hagaman et al., 2016; Han, Oliffe \& Ogrodniczuk, 2013; Han \& Oliffe, 2015; Heredia Montesinos et al., 2019; Zaheer et al., 2018). Changes in social networks and family structures as a result of the migration and resettlement process were shown to increase suicidality, especially for Bhutanese, Korean and Turkish individuals for whom family relationships are of important cultural significance (Brown et al., 2019; Chung, Caine, Barron \& Badaracco, 2015; Han, Oliffe \& Ogrodniczuk, 2013; Heredia Montesinos et al., 2019). Additionally, conflict with family (including between partners, parents and children or wider family networks) was found to be a stressor associated with suicidality in several studies (Brown

et al., 2019; Chung, Caine, Barron \& Badaracco, 2015; Hagaman et al., 2016; Han, Oliffe \& Ogrodniczuk, 2013; Heredia Montesinos et al., 2019). At the same time, several studies found that family support and connectedness with family was a protective factor for many immigrants (Chase 
\& Sapkota, 2017; Chung, Caine, Barron \& Badaracco, 2015; Han \& Oliffe 2015). Degradation of social networks, isolation, lack of social support and loneliness were considered to be contributing factors for suicidality in nearly all included studies.

\section{Theme 4: Heterogeneity of CALD populations}

Of the 18 studies, 10 examined the experiences of a particular ethnic group within another country (Aichberger et al., 2015; Brown et al., 2019; Chase \& Sapkota, 2017; Chung, 2012; Eylem et al., 2019; Hagaman et al., 2016; Han \& Oliffe, 2015; Han, Oliffe \& Ogrodniczuk, 2013; Heredia Montesinos et al., 2019; Zaheer et al., 2018), and the remainder looked at immigrants, refugees or asylum seekers as a group more broadly (Bursztein et al., 2012; Chung et al., 2015; Goosen et al., 2011; Paraschakis et al., 2014; Puzo, Mehlum \& Qin, 2018; van Leeuwen et al., 2010; Vazsonyi, Mikuska \& Gassova, 2017; Westman, 2006). Findings from both groups of studies highlighted the need to consider CALD populations as a heterogenous group when considering prevention strategies. Populations examined within the 18 studies were very diverse, with different risk and protective factors unique to each cultural or ethnic group. This was highlighted as a key limitation in both the studies that looked at a single ethnic group as well as those that examined immigrants as a broader group. For those studies which looked at the experiences of a specific cultural group, the authors warned that findings were contextual to that particular group and could not be generalised to the broader immigrant/refugee experience. Conversely, for the studies which examined the experience of immigrants as a broader group, the authors warned that results may have been skewed, or that findings lacked cultural context. 


\section{Theme 5: Suggested intervention/ prevention directions}

Twelve studies offered recommendations for future prevention efforts, most of which centred on the development of culturally sensitive and multidimensional approaches. In highlighting the relationship between social connectedness and suicidality, two studies called for interventions aimed at strengthening social connectedness and integration, both within the individual's own cultural community as well within the broader local community (Chase \& Sapkota, 2017; Puzo et al., 2018). Building on this theme, one study highlighted the need to develop "holistic mental health treatment and suicide prevention approaches", with a greater focus on the impact of social environments and relational processes (Brown et al., 2019). Similarly, two studies also pointed to initiatives which harness family networks as key to suicide prevention (Chase \& Sapkota, 2017; Vazsonyi et al., 2017).

At the policy level, three studies called for improved access to culturally appropriate health services (Chung, 2012; Hagaman et al., 2016; Han \& Olliffe, 2015), as well as cultural competence of mainstream health services (Goosen et al., 2011; Heredia Montesinos et al., 2019) as a means of breaking down barriers to access for CALD populations. The timing of prevention efforts was also highlighted, with one study suggesting interventions should target newly arrived immigrants or refugees (Hagaman et al., 2016). Several studies acknowledged the link between mental health and suicide, and recommended that intervention efforts focus on improving the quality of, and access to, mental health services more generally (Han \& Oliffe 2015; Puzo et al., 2018; Westman 2006). 


\section{Discussion}

\section{Summary of key findings}

This review found no relevant Australian studies, highlighting an important gap in the Australian research on suicide prevention and suicidality among CALD populations. Furthermore, the search did not identify any intervention studies in any context. The review does provide a snapshot of some of the factors associated with suicidality in international CALD populations, as well as suggesting directions for suicide prevention initiatives. A mix of qualitative and quantitative literature was included in the review, with five key themes identified, including acculturation difficulties, stigma, social networks and family, heterogeneity of CALD populations and suggested prevention directions.

\section{Acculturation}

Acculturation was identified as a key factor associated with suicidality within many of the included studies. Acculturation stress is identified in the broader literature as a common outcome in migrants, refugees and asylum seekers (Berry, 2005). It occurs often as a result of the breakdown of social and cultural norms, which can then lead to individual psychological distress. Participants across the studies identified issues and difficulties assimilating into the host culture. This most commonly included language barriers, which then led to not being able or willing to access professional support services or connect with the local community. Acculturation issues were also shown to be associated with difficulties gaining employment, financial stress, social isolation and poor living conditions, all of which increased the risk of suicide among study participants. This finding is consistent with previous reviews which has found a relationship between acculturation 
stress and both depression and suicidal ideation in refugee and immigrant populations (Lai et al., 2017; Wyatt, Ung, Park, Kwon, Trinh-Shevrin, 2015).

Acculturation issues were present across many of the studies including groups from a range of cultural and ethnic backgrounds, so it is likely that these findings are generalisable to the Australian context. A small amount of research has examined acculturation stress in refugees in Australia and its link to mental health and wellbeing more generally (Milner \& Khawaja, 2010; Lumley, Katsikitis \& Statham, 2018; Kovacev \& Shute, 2004; Kartal, Alkemade, Eisenbruch \& Kissane, 2018). While none of this research addresses suicide specifically, it does illustrate that such issues are also relevant to the Australian context, especially given the link between psychological distress, mental illness and suicide. Future prevention efforts should aim to improve the assistance given to newly arrived migrants or refugees with their transition into the Australian community as a means of mediating the stress associated with transition into a foreign culture. Suicide need not be the primary focus of such initiatives, as the benefits of addressing acculturation stress could help to ameliorate associated risk factors such as a lack of social support, language difficulties and barriers to employment and education.

\section{Stigma}

Stigma was highlighted as a key barrier to help-seeking by participants in several of the included studies. A number of reviews have shown stigma to have a detrimental impact on help-seeking (Thornicroft, 2008; Thornicroft et al., 2016; Farrelly et al., 2015). Several studies in the review recommended the implementation of anti-stigma campaigns as a possible prevention approach that would be suitable and acceptable for this population (Heredia Montesinos et al., 2019; Puzo, Mehlum \& Qin, 2018). Several interventions aimed at reducing stigma around mental illness and 
suicide have been developed for CALD communities in Australia, including face-to-face psychoeducation and web-based interventions. However, a 2013 review concluded that there is only limited evidence for their effectiveness (Reavley \& Jorm, 2013), highlighting that while such an approach may be acceptable and feasible for CALD populations, further evaluation is required.

\section{Social networks and family support}

Within the included studies, family relationships and social support were found to be both risk and protective factors, a finding consistent with broader suicide research. The interpersonal theory of suicide emphasises the role of interpersonal stressors - including family conflict and social isolation - in suicidal behaviour (Van Orden et al., 2010), suggesting that these are not risk factors unique to the CALD population. From a sociological perspective, this offers a good starting point for suicide prevention. Social support has been found to be a key protective factor against suicide (Kleiman \& Liu, 2013), with multiple studies establishing a clear link between social support and help-seeking (Whitlock, Wyman \& Moore, 2014; Suka, Yamauchi \& Sugimori, 2015). Strong relationships with adults have been shown to enhance help-seeking in adolescents for emotional distress and suicide (Pisani, Schmeelk-Cone, et al., 2012). Additionally, adolescents who are engaged at school, and who perceive clear social supports available to them, are more likely to seek help for suicidal behaviour and mental illness (Pisani et al., 2012; Pisani et al., 2013). Schoolbased interventions which utilise existing structural supports typically offered by school communities may be an option for targeting suicide prevention for CALD communities. Further research would be required to evaluate the acceptability and effectiveness of such an approach in this population. 


\section{Limitations}

Several limitations and gaps were identified in the existing literature, in particular regarding the types of studies included in the review. Firstly, no Australian studies were identified through the search. While inferences can be made about the applicability of the findings to the Australian context, further research involving CALD populations within Australia is required to gain an accurate understanding of the associated factors and develop appropriate suicide prevention approaches.

The review included a mix of both qualitative and quantitative studies, as well as studies with vastly different sample sizes (ranging from 15 to 4.4 million), and methodology. No longitudinal studies or intervention studies were identified, and therefore it was not possible to look at the impact of suicidality over time in a given population or examine the effectiveness of existing prevention interventions. The quality assessment indicated that studies were not of strong methodological quality, and hence caution should be exercised when generalising the findings.

One of the key themes identified in the review was the heterogeneity of CALD populations. Most studies examined specific cultural groups making it difficult to generalize the findings. Furthermore, some studies involved immigrant populations, whereas others involved refugees; two groups with different risk profiles. It is therefore difficult to identify particular risk or protective factors specific to the Australian CALD population as a whole due to the diversity of cultures, ethnicities, identities and experiences (migrant or refugee) which make up this group. A key challenge for suicide prevention initiatives therefore will be to develop appropriately targeted and culturally-appropriate interventions which reach as wide an audience as possible. From a policy perspective, universal prevention approaches may be unsuitable for this population as they fail to 
take into account individual risk or protective factors. It may be the case that numerous smallerscale, targeted prevention approaches are introduced instead as a means of addressing the needs of the numerous and diverse CALD communities in Australia.

\section{Policy, research and practice implications}

This review clearly highlights the need for a greater focus in Australia on suicide prevention research, policy and practice for CALD communities. To gain a greater understanding of effective prevention approaches, research into prevalence rates is required as the first step to assess the magnitude of the problem, and appropriately plan future prevention interventions. Given the heterogeneity of the CALD population, it would be most useful to identify particular ethnic or cultural groups who may be at increased risk in order to plan more targeted prevention efforts. In Australia, data on rates of suicide are limited, with many calling for improvement and expansion of surveillance data (Sutherland et al., 2018). While Victoria and Queensland both have suicide registers (including data on CALD status), there is a need for national registry data to capture the rates of suicide among CALD populations across all states and territories.

In addition to investigating rates of suicide, further research looking at risk and protective factors associated with suicide in this population is also required to inform both policy and practice around culturally appropriate and targeted prevention initiatives. A key challenge for researchers and policy makers is the rapidly changing characteristics of the Australian population. Over the past 20 years the number of refugees and migrants has increased, with shifting trends among different ethnic and cultural groups. It is therefore difficult to accurately capture factors associated with suicide in this population as a whole. Research needs to be more targeted in its sample 
selection and examine the experience of single cultural or ethnic groups only (something which could be guided by prevalence data).

In Australia, while government policy is shifting in focus toward greater spending on mental health research and services, there is still only limited funding allocated to suicide prevention each year (Australian Institute of Health and Welfare, 2019). Examples of current suicide prevention efforts in Australia include an array of digital health information resources on mental health and suicide (for example, Beyond Blue, headspace and Black Dog Institute), crisis support helplines (for example Lifeline), and most recently a national media campaign ('YouCanTalk') aimed at family and friends of those who may be experiencing suicidal behaviour as a way of empowering them to have a conversation about. Unfortunately, these initiatives are all limited in their accessibility for CALD populations, as they take a universal prevention approach, and do not offer culturally-targeted variations. Australia's Fifth National Mental Health and Suicide Prevention Plan calls for action to increase access to services from people from CALD communities, particularly digital delivery service platforms.

The development of new, culturally-appropriate prevention initiatives comes at huge expense, and adapting existing mainstream prevention programs could be more cost-effective. Here the focus would be on improving engagement of CALD communities in existing programs, as a means of improving inclusion and accessibility for all members of the Australian population. Airhihenbuwa's PEN-3 cultural model of health behaviour may be useful for guiding this approach (Airhihenbuwa, Ford \& Iwelunmor, 2013). Developed as a means of placing culture at the centre of public health and health education, the model can be used to inform intervention and promotion approaches by identifying the positive aspects of culture. The model emphasises that "(a) all cultures have positive attributes, which is particularly important when health promotion efforts 
occur outside of an interventionist's own culture; and (b) family and community contexts are important determinants of health behaviors". (p.79). Shown to be effective in a range of health settings (Iwelunmor, Newsome \& Airhihenbuwa, 2013), such a model could also be applied in the suicide prevention context.

Co-design (or participatory design) principles of involving those people for whom a product or service is designed for in the decision-making process may also be useful in this context (Hagan et al. 2012). Co-design seeks to understand the lived-experience of users, and would directly involve members of CALD communities having input on decision making and recommendations. Working directly with community members in the design of suicide prevention responses may lead to new ways of understanding the factors associated with suicide in that population, and better tailoring of prevention initiatives. It may also help to build credibility and rapport with community members, which could then also improve engagement and uptake.

Finally, there is a need for evaluation of existing programs. The small number of suicide prevention programs for CALD populations in Australia are yet to be evaluated - highlighting another key gap. Evaluation could look at how to improve access to existing mainstream suicide prevention programs or adapt programs to be more culturally-appropriate.

\section{Conclusion}

This review highlights the need for a greater focus on suicide prevention in Australian CALD communities across policy, research and evaluation. The absence of any published Australian studies means that the findings have drawn on international literature to examine initiatives in reducing suicide in overseas CALD populations. The review also highlights the complexity of conducting research with this population, due to the broad range of cultural and ethnic groups 
within it. While broad themes related to acculturation difficulties, social connectedness and stigma were identified, many of the studies presented results that were context specific, and not generalizable outside of the particular cultural group of interest. In the current geopolitical climate, trends in migration can shift in a relatively short period of time. The makeup of different cultural groups within CALD communities can shift rapidly, and so exploring the experience of CALD communities as a whole may not be useful in designing and implementing suicide prevention initiatives. Prevention efforts need to be targeted to specific cultural groups, while also exploring how to better engage CALD populations in existing mainstream programs and services. 


\section{References}

Aichberger, M. C., Heredia Montesinos, A., Bromand, Z., Yesil, R., Temur-Erman, S., Rapp, M. A., ... Schouler-Ocak, M. (2015). Suicide attempt rates and intervention effects in women of Turkish origin in Berlin. European Psychiatry, 30(4), 480-485. doi:10.1016/j.eurpsy.2014.12.003.

Australian Bureau of Statistics (ABS) (1999). 1289.0 - Standards for statistics on cultural and language diversity. Retrieved from http://www.abs.gov.au/Ausstats/abs@.nsf/mf/1289.0.

Australian Bureau of Statistics (ABS) (2019). 3412.0 - Migration, Australia, 2017-18. Retrieved from https://www.abs.gov.au/ausstats/abs@.nsf/Latestproducts/3412.0Main\%20Features2201718? opendocument \&tabname=Summary \&prodno=3412.0\&issue=2017-18\&num=\&view $=$.

Australian Institute of Health and Welfare (AIHW) (2019). Mental health services in Australia. Retrieved from https://www.aihw.gov.au/reports/mental-health-services/mental-health-servicesin-australia/report-contents/expenditure-on-mental-health-related-services.

Airhihenbuwa, C. O., Ford, C. L., \& Iwelunmor, J. I. (2013). Why culture matters in health interventions: Lessons from HIV/AIDS stigma and NCDs. Health Education \& Behavior, 41(1), 78-84. doi:10.1177/1090198113487199.

Australian Government Department of Health (2014). Evaluation of suicide prevention activities: Final report. Retrieved from http://www.health.gov.au/internet/main/publishing.nsf/Content/4FD5C304C536BDE3CA257CA F0017ADE9/\$File/evalsuic.pdf.

Australian Government Department of Health (2018). Fact sheet: Mental health services for people of culturally and linguistically diverse (CALD) backgrounds. Retrieved from http://www.health.gov.au/internet/main/publishing.nsf/Content/mental-multi-fact.

Barney, L. J., Griffiths, K. M., Jorm, A. F., \& Christensen, H. (2006). Stigma about depression and its impact on help-seeking intentions. Australian \& New Zealand Journal of Psychiatry, 40(1), 51-54.

Berry, J. W. (1997). Immigration, acculturation, and adaptation. Applied Psychology, 46(1), 534.

Berry, J. W. (2005). Acculturation: Living successfully in two cultures. International Journal of Intercultural Relations, 29(6), 697-712. doi:10.1016/j.ijintrel.2005.07.013.

Brown, F. L., Mishra, T., Frounfelker, R. L., Bhargava, E., Gautam, B., Prasai, A., \& Betancourt, T. S. (2019). 'Hiding their troubles': a qualitative exploration of suicide in Bhutanese refugees in the USA. Global Mental Health, 6, e1. doi:10.1017/gmh.2018.34.

Bursztein Lipsicas, C., Makinen, I. H., Apter, A., De Leo, D., Kerkhof, A., Lonnqvist, J., . . . Wasserman, D. (2012). Attempted suicide among immigrants in European countries: An international perspective. Social Psychiatry and Psychiatric Epidemiology, 47(2), 241-251. doi:10.1007/s00127-010-0336-6. 
Chase, L., \& Sapkota, R. P. (2017). "In our community, a friend is a psychologist": An ethnographic study of informal care in two Bhutanese refugee communities. Transcultural Psychiatry, 54(3), 400-422. doi:10.1177/1363461517703023.

Chung, I. (2012). Sociocultural study of immigrant suicide-attempters: An ecological perspective. Journal of Social Work, 12(6), 614-629. doi:10.1177/1468017310394240.

Chung, I. W., Caine, E. D., Barron, C. T., \& Badaracco, M. A. (2015). Clinical and psychosocial profiles of Asian immigrants who repeatedly attempt suicide. Crisis, 36(5), 353-362. doi:10.1027/0227-5910/a000334.

Critical Appraisal Skills Program (CASP) (2019). CASP Qualitative Checklist. Retrieved from https://casp-uk.net/casp-tools-checklists/.

Effective Public Health Practice Project (1998). Quality assessment tool for quantitative studies. Retrieved from https://www.nccmt.ca/knowledge-repositories/search/14.

EndNote (2019). EndNote X9 . Retrieved from https://endnote.com.

Eylem, O., Dalḡar, İ., İnce, B. Ü., Tok, F., van Straten, A., de Wit, L., . . Bhui, K. (2019). Acculturation and suicidal ideation among Turkish migrants in the Netherlands. Psychiatry Research, 275, 71-77. doi:10.1016/j.psychres.2019.02.078.

Farrelly, S., Jeffery, D., Rüsch, N., Williams, P., Thornicroft, G., \& Clement, S. (2015). The link between mental health-related discrimination and suicidality: Service user perspectives. Psychological Medicine, 45(10), 2013-2022. doi:10.1017/S0033291714003158.

Fazel, M., Wheeler, J., \& Danesh, J. (2005). Prevalence of serious mental disorder in 7000 refugees resettled in western countries: A systematic review. The Lancet, 365(9467), 1309-1314. doi:10.1016/S0140-6736(05)61027-6.

Forte, A., Trobia, F., Gualtieri, F., Lamis, D. A., Cardamone, G., Giallonardo, V., . . Pompili, M. (2018). Suicide risk among immigrants and ethnic minorities: A literature overview.

International Journal of Environmental Research and Public Health, 15(7). doi:10.3390/ijerph15071438.

Goosen, S., Kunst, A. E., Stronks, K., van Oostrum, I. E., Uitenbroek, D. G., \& Kerkhof, A. J. (2011). Suicide death and hospital-treated suicidal behaviour in asylum seekers in the Netherlands: a national registry-based study. BMC Public Health, 11(1), 484. doi:10.1186/14712458-11-484.

Hagaman, A. K., Sivilli, T. I., Ao, T., Blanton, C., Ellis, H., Lopes Cardozo, B., \& Shetty, S. (2016). An investigation into suicides among Bhutanese refugees resettled in the United States between 2008 and 2011. Journal of Immigrant and Minority Health, 18(4), 819-827. doi:10.1007/s10903-015-0326-6.

Hagen, P., Collin, P., Metcalf, A., Nicholas, M., Rahilly, K., \& Swainston, N. (2012) Participatory Design of evidence-based online youth mental health promotion, prevention, early intervention and treatment. Retrieved from 
https://www.westernsydney.edu.au/_data/assets/pdf_file/0005/476330/Young_and_Well_CRC_ IM_PD_Guide.pdf.

Han, C. S., \& Oliffe, J. L. (2015). Korean-Canadian immigrants' help-seeking and selfmanagement of suicidal behaviours. Canadian Journal of Community Mental Health, 34(1), 1730. doi:10.7870/cjcmh-2014-036.

Han, C., L. Oliffe, J., \& S. Ogrodniczuk, J. (2013). Culture and suicide: Korean-Canadian immigrants' perspectives. Ethnicity and Inequalities in Health and Social Care, 6(2/3), 30-42. doi:10.1108/EIHSC-08-2013-0015.

Heredia Montesinos, A., Aichberger, M. C., Temur-Erman, S., Bromand, Z., Heinz, A., \& Schouler-Ocak, M. (2019). Explanatory models of suicidality among women of Turkish descent in Germany: A focus group study. Transcultural Psychiatry, 56(1), 48-75. doi:10.1177/1363461518792432.

Ide, N., Kolves, K., Cassaniti, M., De Leo, D., Ide, N., Kõlves, K., . . De Leo, D. (2012). Suicide of first-generation immigrants in Australia, 1974-2006. Social Psychiatry \& Psychiatric Epidemiology, 47(12), 1917-1927. doi:10.1007/s00127-012-0499-4.

Iwelunmor, J., Newsome, V., \& Airhihenbuwa, C. O. (2014). Framing the impact of culture on health: A systematic review of the PEN-3 cultural model and its application in public health research and interventions. Ethnicity \& Health, 19(1), 20-46.

doi:10.1080/13557858.2013.857768.

Kartal, D., Alkemade, N., Eisenbruch, M., \& Kissane, D. (2018). Traumatic exposure, acculturative stress and cultural orientation: the influence on PTSD, depressive and anxiety symptoms among refugees. Social Psychiatry and Psychiatric Epidemiology, 53(9), 931-941. doi:10.1007/s00127-018-1532-z.

Kleiman, E. M., \& Liu, R. T. (2013). Social support as a protective factor in suicide: findings from two nationally representative samples. Journal of Affective Disorders, 150(2), 540-545. doi:10.1016/j.jad.2013.01.033.

Kovacev, L., \& Shute, R. (2004). Acculturation and social support in relation to psychosocial adjustment of adolescent refugees resettled in Australia. International Journal of Behavioral Development, 28(3), 259-267. doi:10.1080/01650250344000497.

Lai, D. W. L., Li, L., \& Daoust, G. D. (2017). Factors influencing suicide behaviours in immigrant and ethno-cultural minority groups: A systematic review. Journal of Immigrant and Minority Health, 19(3), 755-768. doi:10.1007/s10903-016-0490-3.

Law, C.k., Kolves, K., \& De Leo, D. (2014). Suicide mortality in second-generation migrants, Australia, 2001-2008. Social Psychiatry and Psychiatric Epidemiology, 49(4), 601-608. doi:10.1007/s00127-013-0769-9.

Liberati, A., Altman, D. G., Tetzlaff, J., Mulrow, C., Gøtzsche, P. C., Ioannidis, J. P. A., . . . Moher, D. (2009). The PRISMA statement for reporting systematic reviews and meta-analyses 
of studies that evaluate health care interventions: Explanation and elaboration. PLOS Medicine, 6(7), e1000100. doi:10.1371/journal.pmed.1000100.

Life in Mind (2019). Culturally and linguistically diverse communities. Retrieved from https://www.lifeinmindaustralia.com.au/about-suicide/other-population-groups/culturally-andlinguistically-diverse-communities.

Lumley, M., Katsikitis, M., \& Statham, D. (2018). Depression, anxiety, and acculturative stress among resettled Bhutanese refugees in Australia. Journal of Cross-Cultural Psychology, 49(8), 1269-1282. doi:10.1177/0022022118786458.

Milner, K., \& Khawaja, N. G. (2010). Sudanese refugees in Australia: The impact of acculturation stress. Journal of Pacific Rim Psychology, 4(1), 19-29. doi:10.1375/prp.4.1.19.

Minas, H., Kakuma, R., Too, L. S., Vayani, H., Orapeleng, S., Prasad-Ildes, R., . . Oehm, D. (2013). Mental health research and evaluation in multicultural Australia: Developing a culture of inclusion. International Journal of Mental Health Systems, 7(1), 23-48. doi: 10.1186/1752-44587-23.

Paraschakis, A., Michopoulos, I., Christodoulou, C., Koutsaftis, F., Lykouras, L., \& Douzenis, A. (2014). Characteristics of immigrant suicide completers in a sample of suicide victims from Greece. International Journal of Social Psychiatry, 60(5), 462-467. doi:10.1177/0020764013496081.

Pisani, A. R., Schmeelk-Cone, K., Gunzler, D., Petrova, M., Goldston, D. B., Tu, X., \& Wyman, P. A. (2012). Associations between suicidal high school students' help-seeking and their attitudes and perceptions of social environment. Journal of Youth and Adolescence, 41(10), 1312-1324. doi:10.1007/s10964-012-9766-7.

Pisani, A. R., Wyman, P. A., Petrova, M., Schmeelk-Cone, K., Goldston, D. B., Xia, Y., \& Gould, M. S. (2013). Emotion regulation difficulties, youth-adult relationships, and suicide attempts among high school students in underserved communities. Journal of Youth and Adolescence, 42(6), 807-820. doi:10.1007/s10964-012-9884-2.

Potts, B., Kõlves, K., O'Gorman, J., \& De Leo, D. (2015). Suicide in Queensland, 2011-2013: Mortality rates and related data. Retrieved from www.griffith.edu.au/_data/assets/pdf_file/0030/359715/Suicide_in_Queensland_web.pdf.

Puzo, Q., Mehlum, L., \& Qin, P. (2018). Rates and characteristics of suicide by immigration background in Norway. PLoS ONE, 13(9), e0205035. doi:10.1371/journal.pone.0205035.

Reavley, N., \& Jorm, A. (2013). Community and population-based interventions to reduce stigma associated with depression, anxiety and suicide: a rapid review. Retrieved from https://www.saxinstitute.org.au/wp-content/uploads/ECheck_REPORT_Reducing-stigma2013.pdf.

Suka, M., Yamauchi, T., \& Sugimori, H. (2015). Relationship between individual characteristics, neighbourhood contexts and help-seeking intentions for mental illness. BMJ Open, 5(8), e008261. doi:10.1136/bmjopen-2015-008261. 
Sutherland, G., Milner, A., Dwyer, J., Bugeja, L., Woodward, A., Robinson, J., \& Pirkis, J. (2018). Implementation and evaluation of the Victorian Suicide Register. Australian and New Zealand Journal of Public Health, 42(3), 296-302. doi:10.1111/1753-6405.12725.

Thornicroft, G. (2008). Stigma and discrimination limit access to mental health care. Epidemiology and Psychiatric Sciences, 17(1), 14-19. doi:10.1017/S1121189X00002621.

Thornicroft, G., Mehta, N., Clement, S., Evans-Lacko, S., Doherty, M., Rose, D., ... Henderson, C. (2016). Evidence for effective interventions to reduce mental-health-related stigma and discrimination. The Lancet, 387(10023), 1123-1132. doi:10.1016/S0140-6736(15)00298-6.

van Leeuwen, N., Rodgers, R., Régner, I., \& Chabrol, H. (2010). The role of acculturation in suicidal ideation among second-generation immigrant adolescents in France. Transcultural Psychiatry, 47(5), 812-832. doi:10.1177/1363461510382154.

Van Orden, K. A., Witte, T. K., Cukrowicz, K. C., Braithwaite, S. R., Selby, E. A., \& Joiner Jr, T. E. (2010). The interpersonal theory of suicide. Psychological Review, 117(2), 575-600. doi:10.1037/a0018697.

Vazsonyi, A. T., Mikuska, J., \& Gassova, Z. (2017). Revisiting the immigrant paradox: Suicidal ideations and suicide attempts among immigrant and non-immigrant adolescents. Journal of Adolescence, 59, 67-78. doi:10.1016/j.adolescence.2017.05.008.

Westman, J., Sundquist, J., Johansson, L. M., Johansson, S. E., \& Sundquist, K. (2006). Country of birth and suicide: A follow-up study of a national cohort in Sweden. Archives of Suicide Research, 10(3), 239-248. doi:10.1080/13811110600582471.

Whitlock, J., Wyman, P. A., \& Moore, S. R. (2014). Connectedness and suicide prevention in adolescents: pathways and implications. Suicide and Life-Threatening Behavior, 44(3), 246-272. doi:10.1111/sltb.12071.

World Health Organization (WHO) (2018a). National suicide prevention strategies: progress, examples and indicators. Retrieved from https://apps.who.int/iris/bitstream/handle/10665/279765/9789241515016-eng.pdf?ua=1.

World Health Organization (WHO) (2018b). Preventing suicide: a community engagement toolkit. Retrieved from https://apps.who.int/iris/bitstream/handle/10665/272860/9789241513791eng.pdf?ua=1.

Wyatt, L. C., Ung, T., Park, R., Kwon, S. C., \& Trinh-Shevrin, C. (2015). Risk factors of suicide and depression among Asian American, Native Hawaiian, and Pacific Islander youth: A systematic literature review. Journal of Health Care for the Poor and Underserved, 26(2 0), 191. doi:10.1353/hpu.2015.0059.

Zaheer, J., Eynan, R., Lam, J. S., Grundland, M., \& Links, P. S. (2018). "We went out to explore, but gained nothing but illness": Immigration expectations, reality, risk and resilience in ChineseCanadian women with a history of suicide-related behaviour. Culture, Medicine, and Psychiatry, 42(3), 504-534. doi:10.1007/s11013-018-9566-y. 
Figure 1. Database search terms

\begin{tabular}{|c|c|}
\hline 1 & suicid* \\
\hline 2 & prevent* \\
\hline 3 & 'cognitive behavio* therapy' or CBT or psychotherapy or therap* or 'behavio* therapy' \\
\hline 4 & intervention \\
\hline 5 & program \\
\hline 6 & factor or 'risk factor' or 'protective factor' \\
\hline 7 & 2 or 3 or 4 or 5 or 6 \\
\hline 8 & multicultur* \\
\hline 9 & cultural diversity \\
\hline 10 & culturally diverse \\
\hline 11 & cultural pluralism \\
\hline 12 & pluralism \\
\hline 13 & 'non english language speaking' or 'non english speaking' \\
\hline 14 & refugee* \\
\hline 15 & immigrant* \\
\hline 16 & migrant* \\
\hline 17 & CALD \\
\hline 18 & cultural* and linguistic* diverse \\
\hline 19 & linguistic* divers* \\
\hline 20 & 'cultural minority' \\
\hline 21 & 8 or 9 or 10 or 11 or 12 or 13 or 14 or 15 or 16 or 17 or 18 or 19 or 20 \\
\hline 22 & 1 and 7 \\
\hline 23 & 21 and 22 \\
\hline
\end{tabular}

Search limits: English language; 2000-March 2019; peer-reviewed journals 
Figure 2. PRISMA flow diagram

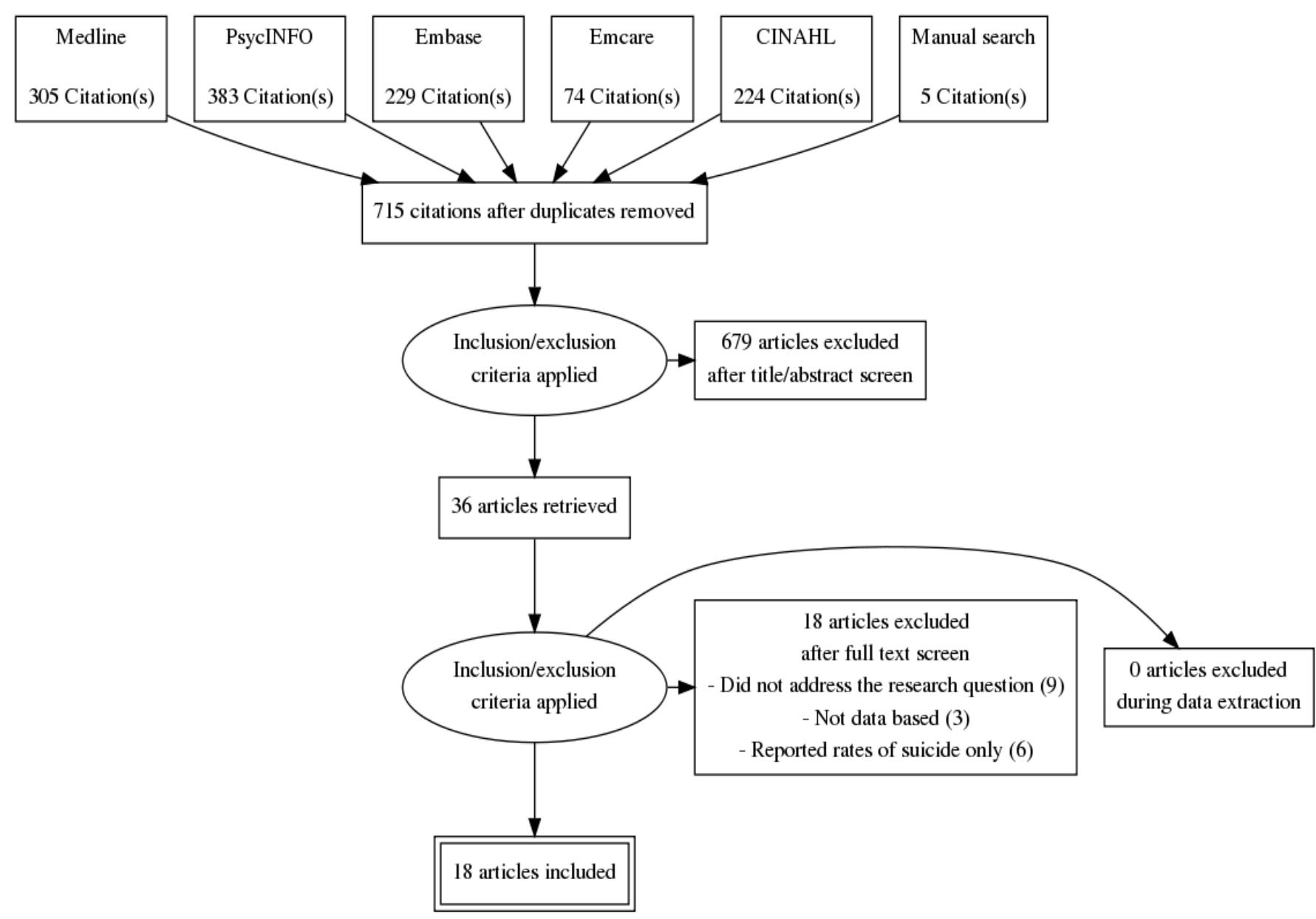


Table 1. Study characteristics or qualitative studies, including country, population, area of focus and key findings.

\begin{tabular}{|c|c|c|c|c|c|c|c|}
\hline Author, year & Country & $\begin{array}{l}\text { Data } \\
\text { collection }\end{array}$ & $\begin{array}{l}\text { Sampling } \\
\text { methodology }\end{array}$ & $\begin{array}{l}\text { Study } \\
\text { population }\end{array}$ & Sample size & Area of focus & Key findings \\
\hline $\begin{array}{l}\text { Brown et al., } \\
2019\end{array}$ & USA & $\begin{array}{l}\text { Focus group } \\
\text { interviews }\end{array}$ & $\begin{array}{l}\text { Snowball- } \\
\text { sampling }\end{array}$ & $\begin{array}{l}\text { Bhutanese } \\
\text { refugees } \\
\text { living in the } \\
\text { US }\end{array}$ & $\mathrm{N}=83$ & $\begin{array}{l}\text { Suicidal } \\
\text { behaviours in } \\
\text { Bhutanese } \\
\text { refugees } \\
\text { living in the } \\
\text { US, including } \\
\text { risk and } \\
\text { protective } \\
\text { factors at } \\
\text { individual, } \\
\text { family, } \\
\text { community } \\
\text { and societal } \\
\text { levels }\end{array}$ & $\begin{array}{l}\text { Several key themes emerged related } \\
\text { to the socio-ecological model of } \\
\text { understanding suicide. These } \\
\text { included resettlement challenges, } \\
\text { taboos around talking about suicide } \\
\text { in the community, family conflict, } \\
\text { loss and grief, social isolation, } \\
\text { cumulative trauma. Findings } \\
\text { support importance of holistic } \\
\text { approaches to suicide prevention } \\
\text { which move beyond the individual } \\
\text { and look at the social environments } \\
\text { in which individuals are situated. }\end{array}$ \\
\hline $\begin{array}{l}\text { Chase \& } \\
\text { Sapkota, } 2017\end{array}$ & $\begin{array}{l}\text { USA and } \\
\text { Nepal }\end{array}$ & $\begin{array}{l}\text { Semi- } \\
\text { structured } \\
\text { individual } \\
\text { interviews; } \\
\text { focus groups }\end{array}$ & $\begin{array}{l}\text { US sample: } \\
\text { Ethnographic } \\
\text { fieldwork in a } \\
\text { Bhutanese } \\
\text { refugee } \\
\text { community. } \\
\text { Nepal sample: } \\
\text { Ethnographic } \\
\text { fieldwork in } \\
\text { Bhutanese } \\
\text { refugee camp }\end{array}$ & $\begin{array}{l}2 \text { groups of } \\
\text { Bhutanese } \\
\text { refugees } \\
\text { living in the } \\
\text { US and a } \\
\text { refugee camp } \\
\text { in Nepal }\end{array}$ & $\begin{array}{l}\mathrm{N}=40 \\
\text { interviews; } \\
\mathrm{N}=4 \text { focus } \\
\text { groups; }\end{array}$ & $\begin{array}{l}\text { The role of } \\
\text { informal care } \\
\text { provided by } \\
\text { family and } \\
\text { community } \\
\text { members in } \\
\text { supporting } \\
\text { suicidal } \\
\text { behaviour and } \\
\text { distress }\end{array}$ & $\begin{array}{l}\text { Heavy reliance on informal care } \\
\text { provided by family, friends and } \\
\text { neighbours as a primary source of } \\
\text { support for Bhutanese refugees. A } \\
\text { range of informal interventions } \\
\text { adopted by this population to } \\
\text { manage distress including financial } \\
\text { support, social mediation and } \\
\text { political advocacy. More formalised } \\
\text { suicide prevention initiatives should }\end{array}$ \\
\hline
\end{tabular}




\begin{tabular}{|c|c|c|c|c|c|c|c|}
\hline & & & $\begin{array}{l}\text { in eastern } \\
\text { Nepal. }\end{array}$ & & & & $\begin{array}{l}\text { focus on regeneration of social } \\
\text { networks. }\end{array}$ \\
\hline Chung, 2012 & USA & $\begin{array}{l}\text { Semi- } \\
\text { structured } \\
\text { individual } \\
\text { interviews }\end{array}$ & $\begin{array}{l}\text { Convenience } \\
\text { sampling from } \\
\text { mental health } \\
\text { clinics }\end{array}$ & $\begin{array}{l}\text { Chinese } \\
\text { immigrant } \\
\text { community } \\
\text { living in New } \\
\text { York }\end{array}$ & $\mathrm{N}=31$ & $\begin{array}{l}\text { Suicide } \\
\text { attempts }\end{array}$ & $\begin{array}{l}\text { No single cause of suicide } \\
\text { behaviour, but rather an } \\
\text { accumulation of multiple stressors } \\
\text { including acculturation difficulties, } \\
\text { pre-existing mental health issues, } \\
\text { negative life events, negative help } \\
\text { seeking behaviours. Findings } \\
\text { support the need for } \\
\text { multidimensional suicide prevention } \\
\text { strategies, including culturally } \\
\text { appropriate mental health support } \\
\text { services for immigrants specifically; } \\
\text { and community building for the } \\
\text { immigrant population. }\end{array}$ \\
\hline $\begin{array}{l}\text { Chung et al., } \\
2015\end{array}$ & USA & $\begin{array}{l}\text { Medical chart } \\
\text { review and } \\
\text { semi- } \\
\text { structured } \\
\text { individual } \\
\text { interviews }\end{array}$ & $\begin{array}{l}\text { Convenience } \\
\text { sampling at } \\
\text { two major } \\
\text { hospitals in } \\
\text { New York } \\
\text { City }\end{array}$ & $\begin{array}{l}\text { Asian } \\
\text { immigrants } \\
\text { living in the } \\
\text { USA }\end{array}$ & $\begin{array}{l}\mathrm{N}=44 \text { chart } \\
\text { reviews \& } \\
\mathrm{N}=12 \\
\text { interviews }\end{array}$ & $\begin{array}{l}\text { Suicide } \\
\text { attempts; } \\
\text { clinical and } \\
\text { psychosocial } \\
\text { profiles of } \\
\text { Asian } \\
\text { immigrants } \\
\text { who } \\
\text { repeatedly } \\
\text { attempt } \\
\text { suicide }\end{array}$ & $\begin{array}{l}\text { Various factors contributed to } \\
\text { repeated suicide attempts in Asian } \\
\text { immigrants, including persistent } \\
\text { mental illness, social isolation, lack } \\
\text { of support and acceptance from } \\
\text { family, unemployment, feelings of } \\
\text { hopelessness, impulsivity, and poor } \\
\text { coping during times of distress. }\end{array}$ \\
\hline $\begin{array}{l}\text { Hagaman et } \\
\text { al., } 2016\end{array}$ & USA & $\begin{array}{l}\text { Psychological } \\
\text { autopsy }\end{array}$ & $\begin{array}{l}\text { Purposive } \\
\text { sampling of } \\
\text { families of } \\
\text { those who } \\
\text { have died by }\end{array}$ & $\begin{array}{l}\text { Bhutanese } \\
\text { refugees } \\
\text { living in the } \\
\text { US }\end{array}$ & $\mathrm{N}=16$ & $\begin{array}{l}\text { Risk factors } \\
\text { associated } \\
\text { with suicide } \\
\text { in Bhutanese } \\
\text { refugees }\end{array}$ & $\begin{array}{l}\text { Using psychological autopsies, } \\
\text { results found risk factors associated } \\
\text { with suicide in Bhutanese refugee } \\
\text { population to be unemployment, } \\
\text { difficulties with cultural }\end{array}$ \\
\hline
\end{tabular}




\begin{tabular}{|c|c|c|c|c|c|c|c|}
\hline & & & $\begin{array}{l}\text { suicide (as } \\
\text { identified } \\
\text { through the } \\
\text { Office of } \\
\text { Refugee } \\
\text { Resettlement) }\end{array}$ & & & & $\begin{array}{l}\text { assimilation, lack of resettlement } \\
\text { services and social support, } \\
\text { separation from family. Suggested } \\
\text { intervention strategies should focus } \\
\text { on improved community-based } \\
\text { support, outreach, social support, } \\
\text { enhanced mental health screening } \\
\text { and person-centred mental health } \\
\text { programs to help build resilience. }\end{array}$ \\
\hline $\begin{array}{l}\text { Han et al., } \\
2013\end{array}$ & Canada & $\begin{array}{l}\text { Semi- } \\
\text { structured } \\
\text { individual } \\
\text { Interviews }\end{array}$ & $\begin{array}{l}\text { Convenience } \\
\text { sampling via } \\
\text { print and } \\
\text { online media } \\
\text { advertisements } \\
\text { (including in } \\
\text { Korean and } \\
\text { English } \\
\text { newspapers } \\
\text { and web sites, } \\
\text { supermarkets, } \\
\text { restaurants, } \\
\text { college and } \\
\text { university } \\
\text { campuses) }\end{array}$ & $\begin{array}{l}\text { Korean- } \\
\text { Canadian } \\
\text { immigrants }\end{array}$ & $\mathrm{N}=15$ & $\begin{array}{l}\text { To describe } \\
\text { culture- and } \\
\text { context- } \\
\text { specific } \\
\text { suicidal } \\
\text { behaviours } \\
\text { among } \\
\text { Korean- } \\
\text { Canadian } \\
\text { immigrants }\end{array}$ & $\begin{array}{l}\text { Three key themes related to suicidal } \\
\text { behaviour including academic and } \\
\text { work pressures; estranged family; } \\
\text { altered identities. Findings provide } \\
\text { insights into how cultural } \\
\text { background influences values, } \\
\text { beliefs, attitudes and } \\
\text { communication styles around } \\
\text { suicidal behaviours. }\end{array}$ \\
\hline $\begin{array}{l}\text { Han \& Oliffe, } \\
2015\end{array}$ & Canada & $\begin{array}{l}\text { Semi- } \\
\text { structured } \\
\text { individual } \\
\text { Interviews }\end{array}$ & $\begin{array}{l}\text { As above } \\
\text { (same sample) }\end{array}$ & $\begin{array}{l}\text { Korean- } \\
\text { Canadian } \\
\text { immigrants }\end{array}$ & $\mathrm{N}=15$ & $\begin{array}{l}\text { Help-seeking } \\
\text { and self- } \\
\text { management } \\
\text { strategies used } \\
\text { by Korean- } \\
\text { Canadian } \\
\text { immigrants } \\
\text { for suicidal } \\
\text { behaviours }\end{array}$ & $\begin{array}{l}\text { Most participants preferred self- } \\
\text { management strategies rather than } \\
\text { seeking professional help for } \\
\text { suicidal ideation. Reluctance to seek } \\
\text { professional or peer help } \\
\text { underpinned by culturally-informed } \\
\text { stigma. Lack of knowledge about } \\
\text { available services, language and } \\
\text { cultural barriers, led some }\end{array}$ \\
\hline
\end{tabular}




\begin{tabular}{|c|c|c|c|c|c|c|c|}
\hline & & & & & & & $\begin{array}{l}\text { participants to perceive mental } \\
\text { health services as ineffectual. } \\
\text { Findings offer some guidance } \\
\text { toward developing culture-sensitive } \\
\text { suicide prevention programs. }\end{array}$ \\
\hline $\begin{array}{l}\text { Heredia } \\
\text { Montesinos et } \\
\text { al., } 2019\end{array}$ & Germany & Focus groups & $\begin{array}{l}\text { Purposive } \\
\text { sampling of } \\
\text { Turkish- } \\
\text { speaking } \\
\text { health } \\
\text { professionals } \\
\text { and } \\
\text { community } \\
\text { members. }\end{array}$ & $\begin{array}{l}\text { Female } \\
\text { Turkish } \\
\text { immigrants }\end{array}$ & $\begin{array}{l}9 \text { focus } \\
\text { groups } \\
(\mathrm{N}=61)\end{array}$ & $\begin{array}{l}\text { Experiences } \\
\text { of Turkish } \\
\text { women living } \\
\text { in Germany } \\
\text { who have } \\
\text { experienced } \\
\text { suicidality }\end{array}$ & $\begin{array}{l}\text { Younger women, and marriage } \\
\text { migrants were found to be at } \\
\text { increased risk of suicidal behaviour. } \\
\text { Risk factors fell into two key } \\
\text { themes: the impact of family and } \\
\text { community, and the impact of } \\
\text { German society. Findings highlight } \\
\text { urgent need to develop and } \\
\text { implement prevention and } \\
\text { intervention strategies for } \\
\text { immigrant women. }\end{array}$ \\
\hline $\begin{array}{l}\text { Paraschakis et } \\
\text { al., } 2014\end{array}$ & Greece & $\begin{array}{l}\text { Forensic } \\
\text { records and } \\
\text { psychological } \\
\text { autopsies }\end{array}$ & $\begin{array}{l}\text { Purposive } \\
\text { sampling of } \\
\text { families of } \\
\text { those who } \\
\text { have died by } \\
\text { suicide (as } \\
\text { identified } \\
\text { through } \\
\text { Athens } \\
\text { Department of } \\
\text { Forensic } \\
\text { Medicine). } \\
\text { Forensic } \\
\text { records } \\
\text { provided by } \\
\text { same source. }\end{array}$ & $\begin{array}{l}\text { Immigrants } \\
\text { who died by } \\
\text { suicide in } \\
\text { Greece }\end{array}$ & $\mathrm{N}=53$ & $\begin{array}{l}\text { Differences in } \\
\text { risk factors } \\
\text { for suicidal } \\
\text { behaviours } \\
\text { between } \\
\text { Greek } \\
\text { nationals and } \\
\text { immigrants }\end{array}$ & $\begin{array}{l}\text { Immigrants found to have higher } \\
\text { risk of suicide compared to Greek } \\
\text { nationals. Social isolation and } \\
\text { language barriers key risk factors. } \\
\text { Suicide prevention strategies should } \\
\text { focus on identifying immigrant } \\
\text { individuals most at risk of dying by } \\
\text { suicide and addressing their } \\
\text { particular needs. }\end{array}$ \\
\hline
\end{tabular}




\begin{tabular}{|l|l|l|l|l|l|l|l|}
\hline $\begin{array}{l}\text { Zaheer et al., } \\
2018\end{array}$ & Canada & $\begin{array}{l}\text { Semi- } \\
\text { structured } \\
\text { individual } \\
\text { Interviews }\end{array}$ & $\begin{array}{l}\text { Convenience } \\
\text { sampling via } \\
\text { mental health } \\
\text { programs in } \\
\text { Toronto }\end{array}$ & $\begin{array}{l}\text { Female } \\
\text { Chinese } \\
\text { immigrants } \\
\text { living in } \\
\text { Canada }\end{array}$ & N=10 & $\begin{array}{l}\text { Experiences, } \\
\text { stressors and } \\
\text { beliefs of } \\
\text { Chinese- } \\
\text { immigrant } \\
\text { women with a } \\
\text { history of } \\
\text { suicidal } \\
\text { behaviour }\end{array}$ & $\begin{array}{l}\text { Immigration-related stressors } \\
\text { contributed to feelings of } \\
\text { helplessness, hopelessness and } \\
\text { alienation, which are known risk } \\
\text { factors for suicide-related } \\
\text { behaviour, and likely mediate their } \\
\text { risk for suicidal behaviour. }\end{array}$ \\
\hline
\end{tabular}


Table 2. Study characteristics of quantitative studies, including country, population, sampling methodology, area of focus and key findings.

\begin{tabular}{|c|c|c|c|c|c|c|c|}
\hline Author, year & Country & Data collected & $\begin{array}{l}\text { Sampling } \\
\text { methodology }\end{array}$ & Sample size & $\begin{array}{l}\text { Study } \\
\text { population }\end{array}$ & Area of focus & Key findings \\
\hline $\begin{array}{l}\text { Aichberger et } \\
\text { al., } 2015\end{array}$ & Germany & $\begin{array}{l}\text { Age, year of } \\
\text { migration, } \\
\text { intent, } \\
\text { methods used, } \\
\text { treatment, } \\
\text { clinical } \\
\text { diagnoses (by } \\
\text { psychiatrist), } \\
\text { migration } \\
\text { status and } \\
\text { psychosocial } \\
\text { strains }\end{array}$ & $\begin{array}{l}\text { Women who } \\
\text { reported to an } \\
\text { emergency } \\
\text { department } \\
\text { after a suicide } \\
\text { attempt in } \\
\text { Berlin. Data } \\
\text { collected from } \\
\text { both patients } \\
\text { and emergency } \\
\text { department } \\
\text { staff }\end{array}$ & $\mathrm{N}=405$ & $\begin{array}{l}\text { Women of } \\
\text { Turkish } \\
\text { origin in } \\
\text { Germany }\end{array}$ & $\begin{array}{l}\text { Suicide attempt } \\
\text { rates, and } \\
\text { impact of } \\
\text { population- } \\
\text { based media } \\
\text { campaign } \\
\text { (intervention) } \\
\text { aimed at } \\
\text { encouraging } \\
\text { help-seeking for } \\
\text { suicidal } \\
\text { behaviour in } \\
\text { Turkish women }\end{array}$ & $\begin{array}{l}\text { Women of Turkish origin aged } \\
18-24 \text {-year-old had the highest } \\
\text { suicide attempt rate. Intervention } \\
\text { found to have a reduced suicide } \\
\text { attempt rates in this age group } \\
\text { only over a } 29 \text {-month period. }\end{array}$ \\
\hline $\begin{array}{l}\text { Bursztein et al., } \\
2012\end{array}$ & $\begin{array}{l}11 \text { European } \\
\text { countries } \\
\text { involved in } \\
\text { the WHO } \\
\text { Multi-centre } \\
\text { study }\end{array}$ & $\begin{array}{l}\text { Demographic, } \\
\text { psychological, } \\
\text { and socio- } \\
\text { economic } \\
\text { variables, } \\
\text { number and } \\
\text { method(s) of } \\
\text { attempted } \\
\text { suicides }\end{array}$ & $\begin{array}{l}\text { Existing data } \\
\text { collected } \\
\text { through } \\
\text { WHO/EURO } \\
\text { Multicentre } \\
\text { Study on } \\
\text { Suicidal } \\
\text { Behaviour }\end{array}$ & $\begin{array}{l}\mathrm{n}=22,888 \\
\text { local } \\
\text { persons; } \\
\mathrm{n}=4,160 \\
\text { immigrants }\end{array}$ & $\begin{array}{l}\text { Local and } \\
\text { immigrant } \\
\text { persons who } \\
\text { have } \\
\text { attempted } \\
\text { suicide in } 11 \\
\text { European } \\
\text { countries }\end{array}$ & $\begin{array}{l}\text { Rates of suicide } \\
\text { attempts among } \\
\text { immigrants } \\
\text { compared to } \\
\text { host country } \\
\text { populations; } \\
\text { impact of } \\
\text { culture on } \\
\text { suicidal } \\
\text { behaviour }\end{array}$ & $\begin{array}{l}\text { Higher rates of suicide attempts } \\
\text { among immigrants (compared to } \\
\text { host populations) which in some } \\
\text { cases did not mirror rates of } \\
\text { suicide in their countries of origin. } \\
\text { Acculturation and integration } \\
\text { difficulties, and disadvantaged } \\
\text { socioeconomic situation identified } \\
\text { as possible risk factors for suicidal } \\
\text { behaviour. }\end{array}$ \\
\hline $\begin{array}{l}\text { Eylem et al., } \\
2019\end{array}$ & $\begin{array}{l}\text { The } \\
\text { Netherlands }\end{array}$ & $\begin{array}{l}\text { Demographic } \\
\text { data; suicidal } \\
\text { ideation (via }\end{array}$ & $\begin{array}{l}\text { Convenience } \\
\text { sampling } \\
\text { through social }\end{array}$ & $\mathrm{N}=185$ & $\begin{array}{l}\text { Turkish } \\
\text { migrants } \\
\text { living in the }\end{array}$ & $\begin{array}{l}\text { The role of } \\
\text { acculturation in } \\
\text { suicidal ideation }\end{array}$ & $\begin{array}{l}\text { Participation in host culture may } \\
\text { have lower risk of suicidal } \\
\text { ideation. Participation can create }\end{array}$ \\
\hline
\end{tabular}




\begin{tabular}{|c|c|c|c|c|c|c|c|}
\hline & & $\begin{array}{l}\text { Suicide } \\
\text { Probability } \\
\text { Scale); level of } \\
\text { acculturation } \\
\text { (via Lowlands } \\
\text { Acculturation } \\
\text { Scale); } \\
\text { attachment } \\
\text { style (via } \\
\text { Attachment } \\
\text { Style } \\
\text { Relationship } \\
\text { Questionnaire) }\end{array}$ & $\begin{array}{l}\text { media and } \\
\text { liaison with } \\
\text { community } \\
\text { groups }\end{array}$ & & Netherlands & $\begin{array}{l}\text { and suicide } \\
\text { attempts }\end{array}$ & $\begin{array}{l}\text { opportunities for interactions } \\
\text { between groups which can } \\
\text { mediate acculturation difficulties. } \\
\text { Acculturation should be an } \\
\text { essential element of national } \\
\text { mental health policies. }\end{array}$ \\
\hline $\begin{array}{l}\text { Goosen et al., } \\
2011\end{array}$ & $\begin{array}{l}\text { The } \\
\text { Netherlands }\end{array}$ & $\begin{array}{l}\text { Demographics; } \\
\text { suicide deaths } \\
\text { and cases of } \\
\text { attempted } \\
\text { suicide }\end{array}$ & $\begin{array}{l}\text { Existing data } \\
\text { obtained } \\
\text { through } \\
\text { asylum seeker } \\
\text { reception } \\
\text { centres in The } \\
\text { Netherlands }\end{array}$ & $\begin{array}{l}\mathrm{N}=35 \\
\text { suicide } \\
\text { deaths \& } \\
\mathrm{n}=290 \text { cases } \\
\text { of hospital } \\
\text { treated } \\
\text { suicidal } \\
\text { behaviour }\end{array}$ & $\begin{array}{l}\text { Asylum } \\
\text { seekers } \\
\text { living in the } \\
\text { Netherlands }\end{array}$ & $\begin{array}{l}\text { To assess the } \\
\text { burden of } \\
\text { suicide deaths } \\
\text { and those who } \\
\text { had experiences } \\
\text { suicidal } \\
\text { behaviour in the } \\
\text { asylum seekers } \\
\text { population } \\
\text { living in the } \\
\text { Netherlands }\end{array}$ & $\begin{array}{l}\text { Suicide death rate found to be } \\
\text { higher in male asylum seekers } \\
\text { compared to Dutch males (with no } \\
\text { significant findings for females). } \\
\text { Incidence of hospital-treated } \\
\text { suicidal behaviour was higher in } \\
\text { several subgroups of asylum } \\
\text { seekers compared to the Dutch } \\
\text { population. Existing mental health } \\
\text { issues and the asylum procedure } \\
\text { the main risk factors for suicidal } \\
\text { behaviour. Targeted and culturally } \\
\text { appropriate prevention measures } \\
\text { called for. }\end{array}$ \\
\hline Puzo et al., 2018 & Norway & $\begin{array}{l}\text { Demographics; } \\
\text { immigration } \\
\text { background; } \\
\text { method of } \\
\text { suicide; month } \\
\text { of suicide; }\end{array}$ & $\begin{array}{l}\text { Existing data } \\
\text { from } 2 \\
\text { Norwegian } \\
\text { national } \\
\text { longitudinal } \\
\text { registers, }\end{array}$ & $\begin{array}{l}\mathrm{N}=11,409 \\
\text { suicides } \\
\text { total; } \\
\mathrm{N}=1,139 \\
\text { with } \\
\text { immigration }\end{array}$ & $\begin{array}{l}\text { Immigrants } \\
\text { who died by } \\
\text { suicide in } \\
\text { Norway } \\
\text { between } \\
1992 \text { and }\end{array}$ & $\begin{array}{l}\text { Rates and } \\
\text { patterns of } \\
\text { suicide among } \\
\text { immigrants } \\
\text { living in } \\
\text { Norway as well }\end{array}$ & $\begin{array}{l}\text { Suicide rate of first-generation } \\
\text { immigrants comparatively lower } \\
\text { than the suicide rate of native } \\
\text { Norwegians. Partly explained by } \\
\text { healthy migrant effect. Most first- } \\
\text { generation migrants appeared to }\end{array}$ \\
\hline
\end{tabular}




\begin{tabular}{|c|c|c|c|c|c|c|c|}
\hline & & $\begin{array}{l}\text { time since } \\
\text { immigration }\end{array}$ & $\begin{array}{l}\text { including } \\
\text { Cause-of- } \\
\text { Death Register } \\
\text { and Central } \\
\text { Population } \\
\text { Register }\end{array}$ & background & 2012 & $\begin{array}{l}\text { as possible risk } \\
\text { factors }\end{array}$ & $\begin{array}{l}\text { retain the suicide rate of their } \\
\text { country of origin. Knowledge of } \\
\text { immigrant mortality according to } \\
\text { suicide method, seasonality of } \\
\text { suicide, and time since } \\
\text { immigration may be useful when } \\
\text { planning suicide preventive } \\
\text { initiatives. }\end{array}$ \\
\hline $\begin{array}{l}\text { van Leeuwen et } \\
\text { al., } 2010\end{array}$ & France & $\begin{array}{l}\text { Suicidal } \\
\text { ideation; } \\
\text { Acculturation } \\
\text { orientations; } \\
\text { ethnic identity; } \\
\text { Attachment to } \\
\text { parents; } \\
\text { depressive } \\
\text { symptoms; } \\
\text { Borderline } \\
\text { personality } \\
\text { disorder } \\
\text { (BPD) traits, } \\
\text { and } \\
\text { sociodemograp } \\
\text { hic data }\end{array}$ & $\begin{array}{l}\text { Convenience } \\
\text { sampling via } \\
\text { high schools in } \\
\text { Essonne and } \\
\text { Midi-Pyrénées } \\
\text { regions in } \\
\text { France }\end{array}$ & $\mathrm{N}=292$ & $\begin{array}{l}\text { French high } \\
\text { school } \\
\text { students } \\
\text { with an } \\
\text { immigration } \\
\text { background }\end{array}$ & $\begin{array}{l}\text { The impact of } \\
\text { acculturation } \\
\text { orientations on } \\
\text { suicidal ideation } \\
\text { and behaviour } \\
\text { among } \\
\text { adolescents of } \\
\text { immigration } \\
\text { background in } \\
\text { France }\end{array}$ & $\begin{array}{l}\text { Acculturation issues play a key } \\
\text { role in the prediction of suicidal } \\
\text { ideation and behaviour, and reveal } \\
\text { gender-specific patterns of risk } \\
\text { factors; highlighting the } \\
\text { importance of cultural } \\
\text { connectedness and self-continuity. } \\
\text { Findings also have implications } \\
\text { for how multiculturalism is valued } \\
\text { in academic and educational } \\
\text { settings. }\end{array}$ \\
\hline $\begin{array}{l}\text { Vazsonyi et al., } \\
2017\end{array}$ & Switzerland & $\begin{array}{l}\text { Demographics, } \\
\text { suicidal } \\
\text { ideation; } \\
\text { suicide } \\
\text { attempts; } \\
\text { parental } \\
\text { connectedness; } \\
\text { peer } \\
\text { connectedness; }\end{array}$ & $\begin{array}{l}\text { Existing data } \\
\text { collected as } \\
\text { part of Swiss } \\
\text { Multicentric } \\
\text { Adolescent } \\
\text { Survey on } \\
\text { Health. } \\
\text { Participants } \\
\text { recruited }\end{array}$ & $\mathrm{N}=7,287$ & $\begin{array}{l}\text { Adolescents } \\
\text { living in } \\
\text { Switzerland }\end{array}$ & $\begin{array}{l}\text { To explore the } \\
\text { immigrant } \\
\text { paradox in } \\
\text { relation to rates } \\
\text { of suicidal } \\
\text { ideation and } \\
\text { attempts in } \\
\text { immigrant } \\
\text { versus non- }\end{array}$ & $\begin{array}{l}\text { Findings provided mixed support } \\
\text { for the immigrant paradox, } \\
\text { whereby immigrant adolescents } \\
\text { had lower rates of suicidal } \\
\text { ideation compared to native Swiss } \\
\text { adolescents. Depression was } \\
\text { found to be the strongest predictor } \\
\text { of suicidal ideation and attempts } \\
\text { in both groups, hence school- }\end{array}$ \\
\hline
\end{tabular}




\begin{tabular}{|c|c|c|c|c|c|c|c|}
\hline & & $\begin{array}{l}\text { depressive } \\
\text { symptoms }\end{array}$ & $\begin{array}{l}\text { through Swiss } \\
\text { schools }\end{array}$ & & & $\begin{array}{l}\text { immigrant } \\
\text { adolescents } \\
\text { living in } \\
\text { Switzerland }\end{array}$ & $\begin{array}{l}\text { based interventions called for. } \\
\text { Positive family relationships key } \\
\text { protective factor. }\end{array}$ \\
\hline Westman, 2006 & Sweden & $\begin{array}{l}\text { Demographic } \\
\text { data including } \\
\text { country of } \\
\text { birth, gender, } \\
\text { marital status, } \\
\text { socioeconomic } \\
\text { status, } \\
\text { hospitalisation } \\
\text { for psychiatric } \\
\text { disorders and } \\
\text { substance } \\
\text { abuse }\end{array}$ & $\begin{array}{l}\text { Existing } \\
\text { national } \\
\text { registry data } \\
\text { obtained } \\
\text { through } \\
\text { linkage of five } \\
\text { national } \\
\text { databases } \\
\text { (Note: } \\
\text { completion } \\
\text { rate in these } \\
\text { registers is } 96- \\
99 \% \text { since } \\
\text { registration is } \\
\text { mandatory } \\
\text { according to } \\
\text { Swedish law) }\end{array}$ & $\begin{array}{l}\mathrm{N}=4.4 \\
\text { million (i.e., } \\
\text { all } \\
\text { individuals } \\
\text { living in } \\
\text { Sweden } \\
\text { aged } \\
\text { between } 25 \\
\text { and 64) }\end{array}$ & $\begin{array}{l}\text { Swedish } \\
\text { population }\end{array}$ & $\begin{array}{l}\text { Relationship } \\
\text { between country } \\
\text { of birth on } \\
\text { suicidal } \\
\text { behaviour }\end{array}$ & $\begin{array}{l}\text { Suicide rates varied according to } \\
\text { country of birth. Among men the } \\
\text { highest risk of suicide was found } \\
\text { among men from Finland. Among } \\
\text { women the highest risk of suicide } \\
\text { was found among women from } \\
\text { Finland, Poland, and Eastern } \\
\text { Europe. Key factors to prevent } \\
\text { suicide include early detection and } \\
\text { treatment of psychiatric disorders } \\
\text { and/or or substance abuse, } \\
\text { especially among certain } \\
\text { population groups. }\end{array}$ \\
\hline
\end{tabular}


Table 3. Quality assessment of qualitative studies using the Critical Appraisal Skills Programme (CASP) qualitative checklist.

\begin{tabular}{|c|c|c|c|c|c|c|c|c|c|c|}
\hline CASP item & $\begin{array}{l}\text { Brown et } \\
\text { al., } 2019\end{array}$ & $\begin{array}{l}\text { Chase et } \\
\text { al., } 2017\end{array}$ & $\begin{array}{l}\text { Chung, } \\
2012\end{array}$ & $\begin{array}{l}\text { Chung et } \\
\text { al., } 2015\end{array}$ & $\begin{array}{l}\text { Hagaman } \\
\text { et al., } \\
2016\end{array}$ & $\begin{array}{l}\text { Han et al., } \\
2013\end{array}$ & $\begin{array}{l}\text { Han \& } \\
\text { Oliffe, } \\
2015\end{array}$ & $\begin{array}{l}\text { Heredia } \\
\text { Montesin } \\
\text { os et al., } \\
2019\end{array}$ & $\begin{array}{l}\text { Paraschak } \\
\text { is et al., } \\
2014\end{array}$ & $\begin{array}{l}\text { Zaheer et } \\
\text { al., } 2018\end{array}$ \\
\hline $\begin{array}{l}\text { 1. Was there a } \\
\text { clear statement } \\
\text { of the aims of } \\
\text { the research? }\end{array}$ & Yes & No & No & Yes & Yes & Yes & No & Yes & Yes & No \\
\hline $\begin{array}{l}2 . \quad \text { Is a } \\
\text { qualitative } \\
\text { methodology } \\
\text { appropriate? }\end{array}$ & Yes & Yes & Yes & Yes & Yes & Yes & Yes & Yes & Yes & Yes \\
\hline $\begin{array}{l}\text { 3. Was the } \\
\text { research } \\
\text { design } \\
\text { appropriate to } \\
\text { address the } \\
\text { aims of the } \\
\text { research? }\end{array}$ & Yes & Can't tell & Can't tell & Yes & Yes & Yes & Yes & Yes & Yes & Can't tell \\
\hline $\begin{array}{l}\text { 4. Was the } \\
\text { recruitment } \\
\text { strategy } \\
\text { appropriate to } \\
\text { the aims of the } \\
\text { research? }\end{array}$ & Yes & Can't tell & No & No & Yes & Yes & Yes & Yes & Can't tell & No \\
\hline $\begin{array}{l}\text { 5. Was the data } \\
\text { collected in a } \\
\text { way that } \\
\text { addressed the } \\
\text { research issue? }\end{array}$ & Yes & Can't tell & Can't tell & Yes & Can't tell & Yes & Can't tell & Yes & Yes & Can't tell \\
\hline
\end{tabular}




\begin{tabular}{|c|c|c|c|c|c|c|c|c|c|c|}
\hline $\begin{array}{l}6 . \text { Has the } \\
\text { relationship } \\
\text { between } \\
\text { researcher and } \\
\text { participants } \\
\text { been } \\
\text { adequately } \\
\text { considered? }\end{array}$ & Can't tell & Yes & Can't tell & Can't tell & Yes & Yes & Can't tell & Can't tell & Can't tell & Can't tell \\
\hline $\begin{array}{l}\text { 7. Have ethical } \\
\text { issues been } \\
\text { taken into } \\
\text { consideration? }\end{array}$ & Can't tell & Yes & Yes & No & Yes & Yes & Yes & Yes & Yes & Yes \\
\hline $\begin{array}{l}\text { 8. Was the data } \\
\text { analysis } \\
\text { sufficiently } \\
\text { rigorous? }\end{array}$ & Yes & No & Can't tell & Yes & Yes & Yes & Can't tell & Yes & Yes & Yes \\
\hline $\begin{array}{l}\text { 9. Is there a } \\
\text { clear statement } \\
\text { of findings? }\end{array}$ & Yes & No & Yes & Yes & Yes & Yes & Yes & Yes & Yes & No \\
\hline Rating & Moderate & Poor & Poor & Moderate & High & High & Poor & High & Moderate & Poor \\
\hline
\end{tabular}


Table 4. Quality assessment of quantitative studies using the Quality Assessment Tool for Quantitative Studies checklist

\begin{tabular}{|c|c|c|c|c|c|c|c|c|}
\hline Quality Criteria & $\begin{array}{l}\text { Aichberger } \\
\text { et al., } 2015\end{array}$ & $\begin{array}{l}\text { Bursztein et } \\
\text { al., } 2012\end{array}$ & $\begin{array}{l}\text { Eylem et al., } \\
2019\end{array}$ & \begin{tabular}{|l} 
Goosen et al., \\
2011 \\
\end{tabular} & \begin{tabular}{|lll} 
Puzo & et al., \\
2018 & & \\
\end{tabular} & $\begin{array}{l}\text { Van Leeuwen } \\
\text { et al., } 2010\end{array}$ & $\begin{array}{l}\text { Vazsonyi et al., } \\
2017\end{array}$ & $\begin{array}{l}\text { Westman, } \\
2006\end{array}$ \\
\hline \multicolumn{9}{|l|}{ A. Selection bias } \\
\hline Representativeness & $\begin{array}{l}\text { Somewhat } \\
\text { likely }\end{array}$ & Very likely & Not likely & Very likely & Very likely & Not likely & Very likely & $\begin{array}{l}\text { Very } \\
\text { likely }\end{array}$ \\
\hline Percentage agreed & Can't tell & Can't tell & Can't tell & Can't tell & $80-100 \%$ & Can't tell & $80-100 \%$ & $80-100 \%$ \\
\hline Rating & Moderate & Moderate & Weak & Moderate & Strong & Weak & Strong & Strong \\
\hline \multicolumn{9}{|l|}{ B. Study design } \\
\hline Study design type & Other & Case-control & Other & Other & Other & Other & Other & Other \\
\hline $\begin{array}{l}\text { Described as } \\
\text { randomized? }\end{array}$ & No & No & No & No & No & No & No & No \\
\hline $\begin{array}{l}\text { Method of } \\
\text { randomization } \\
\text { described? }\end{array}$ & n.a. & n.a. & n.a. & n.a. & n.a. & n.a. & n.a. & n.a. \\
\hline $\begin{array}{l}\text { Method } \\
\text { appropriate? }\end{array}$ & n.a. & n.a. & n.a. & n.a. & n.a. & n.a. & n.a. & n.a. \\
\hline Rating & Weak & Weak & Weak & Weak & Weak & Weak & Weak & Weak \\
\hline \multicolumn{9}{|l|}{ C. Confounders } \\
\hline $\begin{array}{l}\text { Pre-intervention } \\
\text { differences? }\end{array}$ & n.a. & n.a. & n.a. & n.a. & n.a. & n.a. & n.a. & n.a. \\
\hline $\begin{array}{l}\text { Percentage } \\
\text { confounders } \\
\text { controlled for }\end{array}$ & n.a. & n.a. & n.a. & n.a. & n.a. & n.a. & n.a. & n.a. \\
\hline
\end{tabular}




\begin{tabular}{|c|c|c|c|c|c|c|c|c|}
\hline Rating & n.a. & n.a. & n.a. & n.a. & n.a. & n.a. & n.a. & n.a. \\
\hline \multicolumn{9}{|l|}{ D. Blinding } \\
\hline $\begin{array}{l}\text { Outcome assessors } \\
\text { were blinded? }\end{array}$ & Can't tell & Can't tell & No & Can't tell & Yes & Can't tell & No & Yes \\
\hline $\begin{array}{l}\text { Participants were } \\
\text { blinded? }\end{array}$ & Can't tell & Can’t tell & No & Can't tell & Yes & Can't tell & No & Yes \\
\hline Rating & Weak & Weak & Weak & Weak & Strong & Weak & Weak & Strong \\
\hline \multicolumn{9}{|c|}{ E. Data collection methods } \\
\hline Valid measures? & Yes & Can't tell & Yes & Yes & Yes & Yes & Yes & Yes \\
\hline $\begin{array}{l}\text { Reliable } \\
\text { measures? }\end{array}$ & Yes & Can't tell & Yes & Yes & Yes & Yes & Yes & Yes \\
\hline Rating & Strong & Weak & Strong & Strong & Strong & Strong & Strong & Strong \\
\hline \multicolumn{9}{|c|}{ F. Withdrawals and dropouts } \\
\hline $\begin{array}{l}\text { Numbers } \quad \text { and } \\
\text { reasons reported } \\
\text { per group? }\end{array}$ & n.a. & n.a. & n.a. & n.a. & n.a. & n.a. & n.a. & n.a. \\
\hline $\begin{array}{l}\text { Percentage } \\
\text { completing study? }\end{array}$ & n.a. & n.a. & n.a. & n.a. & n.a. & n.a. & n.a. & n.a. \\
\hline Rating & n.a. & n.a. & n.a. & n.a. & n.a. & n.a. & n.a. & n.a. \\
\hline Total A-F: & Weak & Weak & Weak & Weak & Moderate & Weak & Weak & Moderate \\
\hline $\begin{array}{l}\text { Number of 'strong' } \\
\text { ratings }\end{array}$ & $1 / 5$ & $0 / 5$ & $1 / 5$ & $1 / 5$ & $3 / 5$ & $1 / 5$ & $2 / 5$ & $3 / 5$ \\
\hline
\end{tabular}

